Article

\title{
Solidarity in Head-Scarf and Pussy Bow Blouse: Reflections on Feminist Activism and Knowledge Production
}

\author{
Lena Gemzöe \\ Department of Ethnology, History of Religions and Gender Studies, Stockholm University, 10691 Stockholm, Sweden; \\ E-Mail: lena.gemzoe@gender.su.se
}

Submitted: 2 May 2018 | Accepted: 12 October 2018 | Published: 22 November 2018

\begin{abstract}
The author of this article discusses the ways in which gender equality and intersectionality are understood and enacted in two recent feminist campaigns in Sweden that use similar techniques to mobilise support for different causes. The first campaign is the so-called Hijab Call-to-Action, a solidarity action that took place in 2013 in which women in Sweden wore a hijab (the Muslim headscarf) for one day in defence of Muslim women's rights. This campaign manifests the ways in which the notion of gender equality brings with it a norm of secularity, but also how the equation of equality and secularity is contested. The second feminist campaign discussed is the so-called Pussy Bow Blouse manifestation that aimed at taking a stand in the controversies surrounding the Swedish Academy as a result of the Metoo campaign in Sweden. The author looks at the political and discursive processes enfolded in these campaigns as a sort of collective learning processes that connect feminist activism and scholarship. A key concern is to critically analyse a binary model of powerless versus gender-equal or feminist women that figure in both debates. Further, the author shows that both campaigns appeal to solidarity through identification, but at the same time underscore the contingent and coalitional nature of identity in the act of dressing in a scarf or a blouse to take on a (political) identity for a day.
\end{abstract}

\section{Keywords}

gender equality; headscarf; feminism; Metoo campaign; Muslim; pussy bow blouse; religion; secularity; solidarity; women

\section{Issue}

This article is part of the issue "Gender Equality and Beyond: At the Crossroads of Neoliberalism, Anti-Gender Movements, 'European' Values, and Normative Reiterations in the Nordic Model”, edited by Lena Martinsson (University of Gothenburg, Sweden), Diana Mulinari (Lund University, Sweden), and Katarina Giritli Nygren (Mid Sweden University, Sweden).

(C) 2018 by the author; licensee Cogitatio (Lisbon, Portugal). This article is licensed under a Creative Commons Attribution 4.0 International License (CC BY).

\section{Introduction}

As recently demonstrated by a group of Swedish feminist scholars (Martinsson, Griffin, \& Nygren, 2016), Sweden's self-image as the most gender-equal nation in the world, what has critically been labelled Swedish "exceptionalism", is being challenged from various angles. Firstly, the notion of perfect Swedish gender equality clashes with the current situation in the country in which victories won in gender equality are threatened by the political effects of a shrinking welfare state, the expansion and strengthening of neoliberal politics and values, and the rise of the right-wing populist party the Sweden Democrats (Mulinari, 2016). Secondly, with its narrow fo- cus on an ideal, white, heterosexual couple, the Swedish norm of gender equality fails to encompass the wider political goals of intersectional feminism; instead it reproduces a range of norms that intersectional feminist activism and scholarship seek to deconstruct (Martinsson, 2016; Martinsson et al., 2016).

I share with these scholars the view that the role played by the notion of gender equality in feminist politics and scholarship needs critical discussion, something which, as Martinsson et al. (2016) stress, does not imply that feminist projects tied to this notion should be abandoned. In this article, I will tie into this discussion by looking at the ways in which gender equality and intersectionality are understood and enacted in two recent femi- 
nist campaigns in Sweden that use similar techniques to mobilise support for different causes. The first campaign is the so-called Hijab Call-to-Action, a solidarity action that took place in 2013 in which women in Sweden wore a hijab (the Muslim headscarf) for one day in defence of Muslim women's rights. This campaign actualises a discussion of the ways in which the notion of gender equality brings with it a norm of secularity, but also how the equation of equality and secularity, and the related religious-secular divide, is now being contested and what this entails for feminist politics and scholarship. The second feminist campaign I discuss is the so-called Pussy Bow Blouse manifestation that aimed at taking a stand regarding the controversies surrounding the Swedish Academy as a result of the Metoo campaign in Sweden. I will look at the political and discursive processes enfolded in these campaigns as a sort of collective learning processes that connect feminist activism and scholarship. A key concern is to critically analyse a binary model of powerless versus gender-equal women that figure in both debates. Can these cases of activism show ways out of the Swedish "exceptionalism" referred to above?

I write from the perspective of being a Swedish anthropologist and gender researcher, working in the EuroAmerican tradition that dominates these fields. I work at the Gender Studies department at Stockholm University, with research interests in gender and religion, culture studies, feminist theory, and activism. I have conducted fieldwork in Sweden, Portugal, Spain, and France in Catholic and Protestant contexts and, therefore, draw most empirical examples from European contexts. I do not practice any religion but have participated in different sorts of activism over the years in feminist, international solidarity, and syndicalist contexts. ${ }^{1}$

\section{Feminism Donning the Veil}

I will start by discussing the Hijab Call-to-Action in solidarity with Muslim women that took place in Sweden in 2013 (see also Gemzöe \& Keinänen, 2016) that addresses gender equality and intersectionality in various ways. The event further illustrates how the religious-secular divide is being contested in current feminist activism and knowledge production. Similar actions take place in Europe and beyond, and in Sweden they have since then become part of the struggle for Muslim women's rights. It started with an incident in a suburb of Stockholm when a pregnant mother of three was physically assaulted by a man who was unacquainted with the victim. He grabbed her hijab, the Muslim headscarf, shouted "people like you should not be here," and bumped her head against a car so hard that she lost consciousness. The incident prompted five women to launch a Hijab Call-to-Action (hijab-upprop in Swedish), exhorting "all co-sisters in Sweden-religious and non-religious" to veil themselves (cover their heads) for one day to show solidarity with all Muslim women who endure violence and harassment (Osman, Doubakil, Rouzbeh, Abdul Fattah, \& Libre, 2013). The call received a massive response and social media was flooded with images of women from different backgrounds, among them several politicians, wearing a hijab. The activists who initiated the call managed to get attention from both media and responsible authorities and could communicate their demand that stronger measures be taken to tackle the discrimination directed toward Muslim women in Swedish society. The responses to the call included critical voices expressing the view that the veil is a symbol of women's oppression and, therefore, using the veil in defence of women's rights would be contradictory. These critical voices continue to be heard, suggesting that wearing a veil to manifest solidarity with Muslim women risks normalising the practice, which stands for an objectification and sexualisation of women (Ögren, 2018). Another critique was that the protest was misguided as it did not involve those who were directly affected, predominated as it was by white, middle-class women who wore the veil for a day with no cost for themselves (cf. Delshad, 2014). The group of activists who launched the call-for-action used the media's attention to stress the differences between Muslim women; not all faithful Muslim women wear a hijab, the reasons for wearing it vary, and most importantly, it should be the right of every Muslim woman to choose freely and neither be forced to wear it, nor discriminated if she does.

The call-to-action speaks to a political situation that Sweden shares with the rest of Europe, where Muslim minorities, often symbolically represented by the veiled Muslim woman, have become the main target of racist and anti-migration forces in Europe. As political scientist Birgit Sauer (2016) shows, although few countries have prohibited the use of the Muslim headscarf in public spaces, negative interpretations of the cloth have spread in European countries, interpretations that associate the veil with the notion that Muslim women stand outside modernity, caught in patriarchal and religious fundamentalism. It is the veil that proves the foreign values and behaviour of "the others", which makes it impossible for them to become truly French, Austrian-or Swedish. Since the solidarity action with Muslim women took place in Sweden, the support for the Sweden Democrats, according to the polls taken during the spring of 2018 ahead of the forthcoming elections this year, has increased. In the same period, the Swedish government, a coalition between the Social democrats and the Green party, has introduced a restriction of immigration policies as a response to the wave of refugees who fled to Europe in the fall of 2015. Although from a comparative,

\footnotetext{
${ }^{1}$ The declaration here of not practicing any religion does not imply that I regard my position as a neutral, secular one from which to study religious others. One of the important insights generated in the 'post-secular turn' is that what is understood as the secularity of Euro-American academia is entangled with the Protestant religious tradition, something which shapes the approaches also to gender and religion in 'secular' academia (Beattie, 2005; Jakobsen \& Pellegrini, 2008).
} 
European perspective, Sweden qualifies as a "tolerant" country regarding headscarf politics as the country's jurisdiction clearly supports Muslim women's right to wear the hijab in public, the existent Islamophobic racism in the country is manifested in hate crimes like mosques set on fire, or the one that triggered the Hijab Call-toAction. Taken together, these developments have, in recent years, effectively torn down Sweden's image as a prime example of international solidarity-the Swedish "exceptionalism" in this area cannot be maintained.

The Hijab Call-to-Action and the image of the veiled Muslim woman it evokes are brought to feminist activism in Sweden by a young generation of Muslim feminist activists, illustrating the point made by Martinsson quoting Irene Molina, Swedish professor in human geography, saying that:

Swedish society should not be too quick to give itself credit for the advanced anti-racist discussions going on in Sweden. Rather, many people with a background in other countries who have struggled for change in Sweden should be recognised for their work. (Martinsson, 2016, p. 204)

The Hijab Call-to-Action elucidates the limitations of a narrow model of gender equality as it poses the question: how can there be gender equality in Sweden if women in headscarves cannot walk the streets without risking assault? In bringing this issue to an arena of feminist struggle in Sweden, the Hijab Call-to-Action connects this struggle to a global political and scholarly debate in which the veil controversies have served as a nodal point.

\section{Gender Equality and Colonial Feminism}

A year after the Hijab Call-to-Action in Sweden, Sarah Delshad (2014), freelance writer and initiator of the Muslim Feminists think tank, wrote about the event and its possible effects on the image of the veiled Muslim woman in Swedish media. She describes the event as one of the few occasions when the debate shed a light on those Muslim, veiled women who see their religious identity as something non-complicated-as opposed to the commonly expressed views that the veil oppresses women. As her own mother figures in the reports on the event as a friend to the victim, reading about it again makes her particularly emotional and she thinks about the mother's life in Sweden. Of the many things her hard-working mother handles in her daily life, Delshad (2014) thinks of the belittling stereotypical image of the veiled Muslim woman that she is constantly confronted with, an image that depicts her as a woman without self-determination.

Delshad's (2014) critique of media representations of veiled Muslim women representing them as powerless addresses what has been at the centre of feminist theoretical debates about veiling, gender, and religion for the last decades. A key point in these debates is that researchers need to find ways to represent women's lives (religious or not) in terms that break down a binary model of the powerless woman versus the gender equal (or feminist) woman. The commitment to such a theoretical task became acute in the political moment when feminism came to play a part in the ideological confrontations between the Western and the Muslim world following the 9/11 terror attack in New York in 2001. The "war against terrorism" launched by the US government was explicitly linked to a project of restoring gender equality in the Muslim world. In the words of Laura Bush, the first lady at the time: "The fight against terrorism is also a fight for the rights and dignity of women." (Abu-Lughod, 2002, p. 784). Feminist anthropologist Lila Abu-Lughod, whose classical text Do Muslim Women Really Need Saving? was developed as a response to this political discourse, points out the deep colonial roots of these ideological constructs and the widespread use of the woman question in colonial policies, which has been labelled "colonial feminism" (Abu-Lughod, 2002, p. 784; Ahmed, 1992). For instance, colonial history is full of examples of colonisers focussing on the veil as a sign of oppression, whereas they at the same time opposed women's suffrage back home. This way of combining colonial feminism with opposition to feminism in the West is repeated in the contemporary veil debates. French feminists have pointed out that the same politicians that systematically oppose any reform concerning women's rights in France, in debates on the veil celebrate 'gender equality' as one of the key liberal values of the French nation. French feminist Christine Delphy commented on this irony declaring that this was how she learnt that gender equality existed in France (Scott, 2007).

The Hijab Call-to-Action, and writers like Delshad (2014), bring forth this whole context when they call attention to the stigmatising effect of the image of the Muslim woman as a woman without self-determination, and through Delshad's (2014) emphasis, the importance of refuting this image also in feminist knowledge production is highlighted. It shows how it is crucial to offer a critique of the image of the Muslim woman as a passive receiver of a patriarchal ideology, widespread not only in political propaganda but also in public debate and academic writing. Scholars working in the field of feminist anthropology specialised in women's lives in Muslim communities have repeatedly emphasised that veiling should not be confused with, or seen as equivalent to, lack of agency. Instead, feminist researchers need to work against "the reductive interpretation of veiling as the quintessential sign of women's unfreedom" (AbuLughod, 2002, p. 786). In her ethnography of a Bedouin community in Egypt (based on fieldwork in the late 1970s and 1980s), Abu-Lughod (1986) describes how "pulling the black head cloth over the face in front of older respected men is considered a voluntary act by women who are deeply committed to being moral and have a sense of honour tied to family." She stresses their selfdetermination in this respect; the Bedouin women de- 
cided for whom they felt it was appropriate to veil (AbuLughod, 1986, 2002). In a similar vein, Saba Mahmood (2005) discusses in her ethnography based on fieldwork in the 1990s in an urban context in Egypt, how middleclass women who joined the mosque movement of religious revival chose to wear the hijab, a form of covering associated with modernity, as an expression of piety. The forms of agency involved, Mahmood suggests, constitute ways of inhabiting norms that cannot be captured in a binary model of oppressor/oppressed.

The lines of argument in the well-known work of these two anthropologists emphasise the importance of refuting interpretations of the veil as simply a sign of oppression and lack of self-determination, which is the negative counterpart of gender equality. ${ }^{2}$ To grasp these women's lives, theoretical notions that go beyond the dichotomous understanding of equality versus powerlessness are needed. The ethnographies of Muslim women contribute to the consciousness that Delshad (2014) calls for as they show that veiling carries many meanings and that the practice does not exclude self-determination. ${ }^{3}$

The cultural heritage of a colonial past and its presence in Sweden's political life is further brought to the attention of the public in the Hijab Call-to-Action through its emphasis on the physical violence in the assault on the veiled woman. Osman et al. (2013) pose the question "what is so frightening about a heavily pregnant veiled woman that makes a full-grown man beat her unconscious?" It is a question that points to the veil's capacity to evoke emotional and violent reactions in western societies. These reactions reveal a deeply sexual, and sexist, dimension of the western obsession with the veil. In her analysis of the 2004 ban on the veil in France, rooted in the country's colonial past with its heritage of discrimination of the French Muslim population, Joan Wallach Scott (2007) recounts numerous examples of French emotional responses to the veil. The responses range from sadness when deprived of the sight of female beauty to outward sexual aggression. The element of sexual aggression as a response to veiling is captured by the psychiatrist Frantz Fanon in a description of male colonisers' attitudes to veiled women in Algeria: "This woman who sees without being seen frustrates the coloniser. There is no reciprocity. She does not yield herself, does not give herself, does not offer herself." (Fanon, 1965, pp. 43-44; Scott, 2007, p. 160). Here, the veil stands for sexual unavailability, an interpretation that, according to Scott (2007), played a crucial role in the contemporary veil controversies in France. In numerous debates, male powerholders and debaters roundly expressed the view that the veil is a kind of aggression that denies men their right to regard and openly desire women in public spaces. In the French debate, the (heterosexual) play between the sexes came to signify a particularly French view of sexuality that was associated with (French, secular) gender equality. Gender equality became synonymous with sexual liberation, which in its turn became synonymous with the visibility of the female body (Scott, 2007). Ripping off Muslim women's veils is the logical companion to this line of thinking. In the summer of 2016, after the terror attack in Nice, French police forced a Muslim woman to undress on a beach in southern France. The police acted on a local prohibition (that later was declared illegal) on wearing the so-called burkini, a full body covering used by some Muslim women on beaches. ${ }^{4}$ Once again Muslim women's bodies became targeted in the western "war against terrorism."

\section{Solidarity in Headscarf: Contesting Gender Equality as a Secular Value}

It is important to note that the Hijab Call-to-Action campaign managed to gather support for the side in the European political landscape that takes a stand against racism and Islamophobic discourses, defending instead migrant's rights to belong without assimilating to nationalist norms regarding religion or clothing. In doing so, Osman et al. (2013) open for an understanding of feminism as implicated in struggles and knowledge projects that tie together gender, sexuality, religion, race/ethnicity, and national belonging.

A solidary action in which Swedish feminists and politicians dress in a hijab, I suggest, goes beyond a mere call for solidarity with migrant communities; the call was for solidarity between "religious and non-religious sisters" and in this way, it seeks to break down the religioussecular divide. Further, it questions the notion of equality as a secular value and puts forward the view that veiled Muslim women can be bearers of equality. The discussion of how gender equality as a concept has been used to legitimise power relations-and warfare as discussed earlier-actualises a critical reappraisal of this notion in feminist theory. The implications of Western feminism's self-understanding as part of a wider Enlightenment discourse in which "equality" is identified with the secular are far-reaching (see Jakobsen \& Pellegrini, 2008). An urgent feminist task has been to show how the discourse of secularity constructs different categories of women as opposed to each another so that the similarities of the structures of power that constrain them are

\footnotetext{
2 The academic literature on the practice of veiling, its regional and historical variations, and significance in the Muslim world (see Hannan \& Gabriel, 2011) as well as the literature on the veil controversies in the Western world is huge. I quote the texts by Lila Abu-Lughod and Saba Mahmood as they have become important to (Western) feminist theory in bridging the gap between the ethnographic understanding of women in Islamic contexts and secular, feminist academia.

${ }^{3}$ It should be underlined that the view that the practice of veiling belongs to the past and hence cannot be used in defence of women's rights is held not only by Westerners but has been common in a range of Muslim countries historically and today, as well as among migrants from Muslim countries residing in Europe (on anti-veiling campaigns in the Muslim world in the interwar period see Cronin, 2014).

${ }^{4}$ Feminist scholars and debaters have questioned the dichotomised understanding (in the French debate as elsewhere) of the covering of the female body in the public sphere as more oppressive than the display of the female body prescribed by fashion in the West.
} 
concealed. As pointed out by Birgit Sauer (2016), the politics of belonging that European nations articulate in the headscarf controversies that are based on a dichotomous understanding of the religious and the secular and seek to exclude (some) women from citizenship, are but another version of the historical exclusion of women from citizenship in European democracies. In addition, the discourse of secularity is now including equality of sexualities as a sign of modernity, as homosexuality is moving from a negative status in secular-liberal societies to a celebrated one, so that to be accepting of homosexuality becomes "a marker of civilization" too (Bracke, 2012, p. 249; Page, 2016). It should be stressed that the strong identification of equality with the secular is not just an abstract notion that needs to be deconstructed. In a recent study of young religious women in the United Kingdom, Sarah-Jane Page (2016) shows how the notion of equality as a secular value affects the lives of these young women profoundly. A common concern for the women in the study, who differ in terms of religious orientation and sexual identity, is the need to negotiate their religious identity in relation to the perceived secular norm of equality-in ways that are not imposed on non-religious young women.

The critical scrutinisation of (gender) equality as a secular, western value is part of a larger critical project engaging with these issues. The historical moment when feminists don the veil as a political gesture corresponds to a parallel theoretical move in feminist academia undertaken in the last decade (Gemzöe \& Keinänen, 2016). The turn to religion as a topic of study in gender studies is part of the so-called post-secular turn in the academy at large. The post-secular turn refers to a reorientation of theories and worldviews that implies a questioning of earlier (Western) convictions that religion would gradually disappear and that the whole world would follow in Europe's footsteps on a path towards secularity and modernity (Asad, 2003; Casanova, 1994). Theorists of secularisation have abandoned their earlier thesis and shown that it is not even valid for America and Europe, which are supposedly the heartlands of secularity and progressivity (Casanova, 1994). The critics of secularisation theories maintain that earlier theories have misrepresented the role and impact of religion historically and point out how religion continues to be a major social force in contemporary societies.

To feminist theory, the post-secular turn is integral to its commitment to intersectionality, as it entails that religion becomes one more "difference" that needs to be accounted for in politics and theory. The Hijab Callto-Action expresses such a political standpoint when a minority group of women facing discrimination due to their "difference" in relation to the native majority calls for solidarity.
To include religion in intersectionality theory, alongside categories like race, ethnicity, sexuality, class, ability, and citizenship entails not only a recognition of the complex political issues involved, as illustrated in the headscarf controversies, but also an inclusion of knowledge regarding this "difference" in the feminist tradition. Recognition of religion as something that divides women requires a deeper engagement on part of feminist studies with gendered, religious subjectivities and with empirical studies and theorising of the ways in which religion (and secularism) function in contemporary societies. The debates that initiated the post-secular turn, and the political reality of solidary actions like the Hijab Call-to-Action in Sweden, make it clearer than ever that feminism needs a global outlook in its theorising. Furthermore, the post-secular turn directs attention to Western feminism's identification with a secular tradition. Intersectionality theory has posed several challenges to Western feminism as each "intersection" has required a critical look at the ways in which feminist thinking itself is marked by the norms it wants to criticise, such as maleness, whiteness, heterosexuality, middle-class belonging, ability, etc. A critical view on the norm of secularity makes visible symbolic structures that work at equally deep levels of thinking, such as the oppositional pairs of hierarchically ordered values like traditional-modern, enlightened-superstitious, progressive-conservative that serve to categorise people and uphold social hierarchies within and between nations. These symbolic structures are important in order to understand the earlier blindness to religion in the Western, feminist academy and the marginalised position of the sub-field of feminist studies of religion and of feminist theology it entailed (King, 2005; for a discussion of the implications of the marginalisation of Religious Studies in secular academia see also Beattie, 2005).

The oppositional pairs referred to above imply an opposition between religious, oppressed women and secularised, gender-equal women, a view that explains, at least partly, why feminist studies of religion prior to the post-secular turn were perceived as concerned with questions of limited relevance to main-stream Western feminist studies. ${ }^{5}$ This position allocated to the sub-field of gender and religion has shaped the field profoundly. A key theme throughout its formation has been to reject the image of religious women as completely powerless and to explore the different forms of agency they deploy. In other words, the line of argument brought to feminist theory in analyses of the veil is not new to feminist research on religion. ${ }^{6}$ On the contrary, feminist researchers have shown how the image of the subdued, passive Religious Woman, indeed the stereotype that Delshad (2014) did not want her mother to be associated with, dominated in (gender-blind) studies of religion, as

\footnotetext{
${ }^{5}$ Feminist conferences and journals responded to the post-secular turn with the same exclamations of "How could we be so blind?" as the rest of the academy. The Feminist Review points out that the 2011 issue was the first to address the subject of religion in the journal's thirty-year-long publishing history. Likewise, the European Feminist conference in 2006 chose religion as its main theme for the first time, and so on.

${ }^{6}$ As discussed elsewhere, in her influential discussion on Muslim women's agency, Mahmood (2005) seems to dismiss earlier feminist studies putting forward similar interpretations of women's religious agency (Gemzöe \& Keinänen, 2016; Woodhead, 2016).
} 
well as in early feminist research. This was partly due to a conflation of religion as a patriarchal symbolic system with the actual role played by women in religious contexts. In Sered's (1999) words, for a long time, Womanas-symbol in male-dominated religious world-views overshadowed real women's involvement in religion. The response by feminist scholars was to emphasise and give weight to the ways in which women across cultures displayed and elaborated forms of agency (even though researchers might use different theoretical language for this purpose). Only by deconstructing the trope of the subdued Religious Woman and refuting the prevailing notion of religious women as lacking in agency could the field of gender and religion be presented as relevant to a secular, feminist academy. ${ }^{7}$ Feminist scholars researching the Christian tradition have struggled with the same image of the subdued Religious Woman that figures in the debates on Muslim women, and its relevance as a theoretical frame has been rejected over and over again (Bynum, Walker, Harrell, \& Richman, 1986; Dubisch 1995; Jantzen, 1995). In my own ethnographic study of Catholic northern Portugal (fieldwork in the 1990s), not only theoretical positions surging in the growing sub-field of gender and religion, but perhaps, even more, the interaction with Portuguese, Catholic women led me to a focus on agency. The self-assertiveness, confidence, and creativity of the women of different ages and classes that I interacted with-indeed the way they presented themselves as religious actors (Gemzöe, 2000)-deconstructed the image of the docile, obedient, and submissive religious woman better than any cultural critique. When my interlocutor and friend, Senhora Marilia, explained to me why she attended mass but did not receive communion, by declaring "I do not kneel in front of a priest to confess my sins, this is between me and God", or when one of the catechists of the community said: "Put me in front of the pope and I will say what I have to say", referring to a heated discussion she had with the priest of her parish, these women made it clear that submissiveness was not a quality they wished for nor felt obliged to cultivate. The class-based anticlericalism of this region was embraced also by pious women. When the Church, implementing the reforms after Vatican II, gave women of this community more space to manoeuvre in the Church, they were quick to use it, expanding in this way their already strong, and to some degree recognised, religious authority and expertise (Gemzöe, 2000, 2009). Yet, women in Catholic cultures devoted to Mary and the saints have hardly been conceived of as bearers of agency, let alone of cultural resistance in feminist contexts (on the Marian cult globally see, for instance, Hermkens, Jansen, \& Notermans, 2009. These blind spots in feminist theorising have to do with the persistence of the binary model of the powerless woman versus the gender equal woman discussed earlier that continues to limit the understandings of religious women's lives.

I suggest that the study of culturally diverse, gendered religious practices, including religious traditions and alternative spiritualities in the presumably secularised west, form an important part of the necessary theoretical reorientations prompted by the post-secular turn, an approach that should be integrated with feminism's theorising of difference. ${ }^{8}$ A turn of attention in empirical studies to Christianity in the West and worldwide as part of a global outlook (although not aimed at excluding attention from other faiths or practices), would further permit a rupture with the exoticisation of the Muslim woman that the Western obsession with the veil has entailed. The focus on the workings of power and agency in research on gender and religion opens for fruitful theoretical encounters with dominant themes in feminist theory-encounters that would allow for a theorising of power that does not distinguish between religious, economic, social, or cultural systems. ${ }^{9}$ An equally important reorientation would involve a reassessment of the place of religious feminism in the history of (Western) feminism, notably what Sands (2008) refers to as "the largest shift in feminism's relation to religion," which is the shift from the religious inspiration of much of firstwave feminism to the secularism of the second wave. But religious feminists need to be made visible in other ways too; the role of religion in the writings of American black feminists (for instance the work of bell hooks), which plays such a crucial role in anti-racist feminism today, needs to be recognised, the work of feminist theologians, whom might be thought of as "religious others" in a secular academy need scholarly attention. ${ }^{10}$ Those religious feminists, be they Goddess feminists, Muslim feminists, or feminist clergy in the Church of Sweden are actually part of a feminist, activist community in need of recognition, not least in Sweden where feminism is perceived as firmly rooted in a secular, political tradition.

The activists launching the Hijab Call-to-Action have, I suggest, initiated and connected the feminist struggle in this area to a global debate and shown that Swedish gender equality, or the struggle for this equality, cannot be an exception to what happens in the rest of the world, it needs to be transnational.

\footnotetext{
${ }^{7}$ The feminist academic response to studies of religion has been described by scholars of gender and religion in texts, conferences, and network meetings, as ranging from mere lack of interest to expressions of ridicule or even aversion, sometimes with claims that the topic does not belong in feminist studies. The responses can largely be explained by the sharp boundaries between religion and a secular, intellectual tradition in which feminism is inscribed (see Beattie, 2005)

${ }^{8}$ In Sweden, such a reorientation, in research or at the level of teaching, would require some work as the curriculum of gender studies programs may well exclude the topic of religion altogether.

${ }^{9}$ See, for instance, Linda Woodhead's concepts of "strategic" and "tactical" religion elaborated to study the interplay and dynamics of power between the level of religious practice in which religious subjectivities are shaped and the institutional level (Woodhead, 2014).

10 The relative lack of interaction between theology and gender studies contributes to the absence of feminist reflection on the Christian tradition and its relation to feminist theory. Vuola (2016) argues that there is a theology blindness in (feminist) studies of religion. See also Walton (2016) for an autoethnographic account of teaching feminist theology.
} 


\section{Symbols of Solidarity in the Political Sphere}

Returning to the Hijab Call-to-Action, it can be noted that the features of the campaign break down some elements in the Western understanding of the political, public sphere as fundamentally different from the sphere of religion, one of the reasons why it is believed they should be kept apart. Whereas religion deals with rituals and symbolism - symbols being the "the currency" of religion as noted by Sered (1999), the political sphere is allegedly governed by rationality. This distinction is evidently contradicted by the many appeals to symbols in political life, the act to show solidarity by donning a veil is one, and as I will turn to in the following, dressing in a pussy bow blouse is another.

The two solidarity campaigns I discuss here are examples of social media activism, a political phenomenon that has expanded rapidly in the recent decades, in Sweden as elsewhere, not least in feminist and antiracist activism. ${ }^{11}$ Although the campaigns also involved encounters in-real-life, such as marches or the activists appearing at work in the veil or the blouse, the solidarity action can be manifested simply by dressing in the garment, taking a selfie and sharing it on Instagram. The fact that the solidarity action is performed by putting on a garment one does not usually wear, which changes one's physical appearance and is all that is needed to participate, is congruent with the digital culture of Facebook or Instagram, where selfies, photos, or other visual messages are used for a constant updating to the world of events in one's life.

The efficiency and speed with which the Hijab Callto-Action could spread in (parts of) Swedish society depended on the impact of its visuality in an already established digital culture. Images of Swedish women wearing a hijab are powerful expressions of solidarity, of bridging the religious and the secular: in an instant, the action puts the Swedish woman in the place of the veiled Muslim woman facing harassment and seems to say: "I am willing to share your vulnerable position and to stand up for your rights." The fact that it "seems to say" something is crucial; the visual message uses the polysemic language of symbols to communicate and must be verbalised to become a political statement with an exact meaning. The call-to-action merges meanings and symbols that have been kept apart or seen as almost antithetical; the symbol of the subordinated, "other" religious woman and the Swedish secular, gender-equal woman. By connecting the feminist and the religious woman, the visual message of the Hijab Call-to-Action opens for a discussion of the relationship between the two. As the image of a veiled woman appears in a feminist campaign, the veil also becomes associated with political agency. ${ }^{12}$ The image of the veiled feminist politician could also be interpreted as a promise to formulate a political, feminist agenda that would seek to take religious rights and identities into account. However, such interpretations of the call-to-action remain an open question, and here lie the limitations of a politics of symbols regardless of the techniques employed to spread the message; paying attention to "religion" as a difference in a feminist politics requires a deep engagement with religious subjectivities and worldviews, something which requires more time and resources than the spreading of photos of women in hijab in social media (which was also one of the critical opinions raised in following debates, as noted earlier). On the other hand, if we look at the campaigns primarily as collective learning processes, it is precisely the images' polysemic nature that makes the actions work. The image manages to communicate different, conflicting meanings that generate further debate and engages more people, in other words, they are excellent triggers of debate and knowledge production. As noted earlier, the issues raised by the Hijab Call-to-Action entail a need of reorientation in the feminist academy to bridge the gap between the religious and the secular in knowledge production. One way of handling this is to stop separating the fields of debate and knowledge from each other. By keeping the two solidarity actions I address here together in one discussion, I seek to take a step, however small it may be, in that direction. So, I now turn to a recent solidary action in Sweden with no reference to religion, but in which another item of clothing, the pussy bow blouse, played a major role.

\section{Feminist Solidary Action in a Pussy Bow Blouse}

The Pussy Bow Blouse manifestation that took place in the spring of 2018 concerns one of the dramatic outcomes of the Metoo campaign in Sweden, namely the crisis it has entailed for The Swedish Academy, the institution in charge of distributing the Nobel Prize in Literature. The events started with a publication in Sweden's largest morning paper, Dagens Nyheter, of 18 women bearing witness to sexual abuse by a man who was linked to the Academy in various ways, and whose cultural work has received economic support from the Academy for more than two decades (Gustavsson, 2017). When these circumstances became public, the Academy was split into factions that disagreed on how to face the crisis. The recently-appointed head of the Academy, Sara Danius, professor of literature and the first female in the position, advocated for a policy of complete openness to handle the crisis, a line of action that did not win the support of a majority in the Academy, and she was forced to resign. The response to her resignation was a massive public protest, which included several researchers at the universities and cultural workers manifesting support for the

\footnotetext{
11 So has research in the field; see, for instance, recent Swedish studies of transnational social media activism by Dahlberg-Grundberg (2016) and Lindell (2011).

12 The veil as a symbol of resistance is not new, as discussed by Scott (2007) in the context of the Algerian liberation war from the French colonial power, and reiterated in Muslim migrant communities all over Europe, where donning the veil might express an independent identity in relation to the dominant culture.
} 
resigned head. The public protests also included a feminist manifestation in which protestors gathered outside the building where the Academy holds its weekly meetings, all wearing the kind of blouse that had become symbolic of the public figure Sara Danius, the former chair: the pussy bow blouse.

Once again, and similarly to the Hijab Call-to-Action, social media were flooded with images of well-known feminists and politicians, among them several of those who wore a hijab for a day some years earlier, now posing in a variety of pussy bow blouses. And just like the Hijab Call-to-Action offers interpretations of veiling that contest the notion of the veiled woman as lacking in selfdetermination, the Pussy Bow Blouse manifestation initiated a process of interpretation of this garment that would change its meaning in several ways. Before I discuss the implications of this event further, I will give a brief background of the Metoo campaign based on Swedish, and international, media's coverage of the events, my aim being to reflect on the themes mentioned above. ${ }^{13}$

The Metoo campaign in which women bear witness to how they have become victims of sexual harassment and assault in their workplaces started with a tweet by American actress Alyssa Milano, after accusations of sexual harassment and assault had been levelled against film-producer Harvey Weinstein by Hollywood actresses (Garcia, 2017). Milano urged her followers to answer her tweet with the words "me too" if they had been victims of sexual abuse or violence. The hashtag Metoo ignited a firestorm on social media, as Facebook, Twitter, Instagram, and other accounts were flooded with support and testimonies from victims of sexual abuse, initiating what would turn into a forceful demonstration of the power of social media activism. However, ten years before Alyssa Milano launched the hashtag Metoo, a nonprofit organisation to help victims of sexual abuse was founded by Tarana Burke, who named her movement Me too. In the first days of the media storm that followed Alyssa Milano's tweet, it was brought to media's attention that the long-time effort by Tarana Burke, who is black, had not received support over the years from prominent white feminists. In the days that followed, Black, Latino, and other women of colour started their own campaign as they saw a disparity in how women of colour were treated when they reported abuse and to use it as a "peaceful moment to say that feminism should be intersectional," in the words of digital media strategist April Reign (Garcia, 2017). Two days after Alyssa Milano sent out her tweet, she publicly thanked and credited Tarana Burke as the founder of Metoo (Garcia, 2017).

The circumstances of how Metoo started in the US show how the campaign can uncover deep cleavages in societies, whereas at the same time it enables solidarity across these divides. As the campaign has spread from country to country, it has developed differently in different national contexts, and discussions of these national differences have been initiated by journalists, debaters, and researchers. Also in Sweden, the Metoo campaign started in professional sectors of the cultural elite, and as it unfolded in the case related to the Swedish Academy, the effects of the Metoo campaign in privileged sectors have been at the centre of the Swedish debate. The campaign started among actresses at the national theatres who bore witness to the sexual harassment and coercion they had been subjected to, revelations that caused scandals and crises within these institutions. ${ }^{14}$ Thereafter, the campaign spread to a wide range of professional groups, from academics and artists to the construction industry and hospitals, to women in criminality and prostitutes, all under the name of hashtags related to their occupation. In the spring of 2018, the Metoo campaign comprised testimonies from almost all sectors of working life, and further included calls-to-action for children, for non-binary gendered persons and for a range of voluntary associations, such as sports movements and Christian churches. In March 2018, 65 Metoo groups presented seven political demands aimed at ending sexism, sexual harassment, and abuse. Commentators have called it the most important women's movement since the struggle for the vote and remark that its mode of organising is characteristic of feminist movements historically: non-hierarchical and spontaneous, spreading from woman to woman who share and speak out about experiences of patriarchal oppression with the contemporarily significant feature that social media is crucial as a tool of consciousness-making and mobilisation. The movement is linked to the wave of feminist activism in the 1970s when the different manifestations of sexual oppression in the heterosexist, patriarchal society were made visible and laws affecting the workplace started to change attitudes and the underlying structures of power that made this oppression possible. ${ }^{15}$ However, one of the distinguishing features of the Metoo campaign in comparison to early activism against sexual oppression in the second wave is its embedment in workplaces and associations. Anna-Klara Bratt (2018), the chief editor of feminist journal Feministiskt perspektiv, has suggested that the high level of gainful labour among Swedish women is one of the factors accounting for this development of the campaign.

Still, the Metoo campaign in its form and content resembles the radical feminism of the 1970s in that its principal message is that women across boundaries of class, sexuality, race or nation, share a condition of being vic-

\footnotetext{
13 The Metoo campaign and its aftermaths are still ongoing processes that continue in new directions and researchers have only begun to document and analyse them. At Stockholm University, the Gender Academy, a network for cross-disciplinary collaboration on gender research, has initiated discussions on how to research Metoo.

14 The campaign started when hundreds of Swedish actresses in theatre and film published narratives of their own experiences of sexual abuse in a collective letter and online with the hashtag "silenceaction" during the fall of 2017.

15 In Sweden, one key feminist action was a protest in 1976 that gathered all feminist and women's organisations against a suggestion to change the jurisdiction on rape in a sex-liberal direction that considered the behaviour of the victim (Thomsson, 2000).
} 
tims of sexual abuse and violence; it is the massive witnessing of this shared form of oppression that accounts for the political force of the campaign. The emphasis on a shared oppression has been accompanied by the concern among activists and researchers that feminism should be intersectional. A main issue in this respect has been whose voices are heard in the campaign, and whose narratives are given attention. Since the campaign started among the actresses there have been various efforts to make visible the long-time work of voluntary organisations, among them the centres who assist victims of rape and abuse (kvinnojourer in Swedish), and of social workers, lawyers, and researchers. For instance, debater and feminist activist Alexandra Pascalidou (2017), who collected different voices of the campaign in a book, partly motivated by a wish to transform the testimonies on social media into a more permanent form, claims to also give voice to those who might not feel addressed by the Metoo movement (see also van Luik, 2017). In this collection of texts, testimonies from well-known feminists of the cultural elite are published together with texts by women who have been working with victims of sexual abuse for a long time, among them the association Terrafem, which assists women in migrant communities. Similarly to what happened in the US, these efforts seek to link the Metoo campaign as represented in conventional media, with its attention to white women of the cultural elite, to the work of voluntary organisations targeting less privileged women. ${ }^{16}$ However, as the events unfolded, the cultural elite continued to be at the centre of the debate related to the Metoo campaign in Sweden as the focus shifted to the crisis of the Swedish Academy and the Pussy Bow Blouse manifestation in the spring of 2018.

What meanings were attached to this solidary action and how is gender equality and intersectionality actualised? The similarities with the Hijab Call-to-Action due to their shared features as social media activism using selfies should be noted. The campaign spread rapidly and received a great deal of attention in social and traditional media, many politicians, both female and male, dressed in the pussy bow blouse. Critical voices soon questioned whether politicians, including ministers, should take a stand in favour of one of the factions in the Swedish Academy-if this was what they meant when dressing in the blouse. The symbolic gesture of dressing in the blouse could, similarly to the symbolic use of veiling for a day, be interpreted in a variety of ways. The critique that ministers should not take a stand in the Swedish Academy's internal affairs was directed at the Minister of
Culture Alice Bah Kuhnke from the Green party, whose selfie in the pussy bow blouse the morning after Sara Danius' resignation became widespread and commented on. However, she refuted the critique and interpreted the act of dressing in a pussy bow blouse, not as taking a stand for or against any member of the Swedish Academy, but for the larger feminist goals at stake. Her selfie was accompanied by a text ${ }^{17}$ saying that "the feminist struggle happens every day.... One step back yesterday means at least two steps forward today" (Khunke, 2018). This was one of the many ways in which the Pussy Bow Blouse manifestation initiated debate and added further meanings to the blouse. The Swedish minister's selfie in a white pussy bow blouse and her text linking it to feminist struggle spread in international media and contributed to the transformation of the pussy bow blouse into a symbol of feminist resistance.

The issue of whether donning a pussy bow blouse could count as a feminist statement was one of the controversies that the campaign gave rise to-much in the same way as the issue of whether donning a veil can serve to defend women's rights. The difficulties in the pussy bow blouse campaign were not only the polysemic qualities of the garment, but that so little was known about the reasons for Sara Danius' resignation because of the secrecy of the Swedish Academy's internal affairs.

The feminists who had organised the pussy bow blouse manifestation, however, argued that there was enough knowledge to take a stand. ${ }^{18}$ They pointed out the deep irony of the fact that the result of the events was that the woman who had taken on the task of sorting out and taking responsibility for the part played by the Academy in what had happened to the 18 witnessing women had been forced to resign, whereas the men in the Academy who had worked against her stayed on. ${ }^{19}$ The protestors pointed out that, once again, a powerful woman who had ascended to leadership over men in society's upper hierarchies had to leave, this time when trying to work against sexual discrimination and 'expressions of the denigration of women,' as Danius wrote in a statement after her resignation (Holmqvist, 2018). The pussy bow blouse was the perfect symbol for this message, carrying meanings that immediately evoke gender and power. The feminist history of the blouse, as it was referred to in media, was widely spread in the aftermath of the manifestation (Tidningarnas telegrambyrå, 2018). This history told about how the pussy bow blouse, which became fashionable when women started to use it as a female counterpart to the tie when they entered whitecollar professions in offices and institutions in the 1950s

16 Historians Klara Arnberg and Helena Tolvhed (2019) relate the Metoo campaign to other social media campaigns in feminist, anti-racist activism, such as the hashtag "svartkvinna" (black woman).

17 The entire text published on the minster's Instagram reads as follows: “En ny dag gryr. Den feministiska kampen sker varje dag, det vet vi så väl. På bussen, i korridoren på skolan, i mötesrummet på jobbet. Ett steg tillbaka igår, betyder minst två steg framåt idag [A new day breaks. The feminist struggle happens every day, we know that so well. On the bus, in the corridor at school, in the meeting room at work. One step back yesterday, means at least two steps forward today]" (Khunke, 2018, my translation).

18 The manifestation arranged on Thursday, April 19, 2018, gathered around 2,000 people. Several feminist politicians were present (Nilsson, 2018).

19 The gender dimension of this turn of events was complicated by the fact that the accused man is married to a female member of the Swedish Academy and that there were women (and men) on both sides of the split. The feminist approach to the handling of accusations of sexual harassment, however, was led and defended by women, the former head Sara Danius, and the author Sara Stridsberg, who also resigned later. 
and onwards, speaks of the history of women's struggles to adapt to a male-dominated professional world. The next generation of women, some of them joining the women's movement of the 1970s, did not dress in pussy bow blouses, associated as they were with the conventional, adaptive femininity of the generation of their mothers who dressed in what was sometimes called "secretary blouses." In the 1980s, the blouse's associations did not become more appealing to feminists as it was associated with ruthless career women, being a favourite outfit of Margaret Thatcher. In the aftermath of the manifestation in 2018, experts and fashion researchers pointed out how, in the last decades, the pussy bow blouse has been re-evaluated, partly as the result of prominent designers' updating of the blouse, making it fashionable again. In Sweden, Sara Danius' use of the blouse in her position as the first female head of the Swedish Academy contributed to turning it into a symbol of women breaking the glass ceiling and entering previously male-dominated centres of power.

The Pussy Bow Blouse manifestation illustrates one of the immediate political effects of the Metoo campaign in Sweden and elsewhere, namely its capacity to move from the issue of sexual harassment at the individual level to the larger structures of power at workplaces, or to society at large. The manifestation further accentuated the focus on working conditions that the formation in professional groups of the Metoo campaign in Sweden entails. In this way, it drew together two feminist struggles; the message of putting an end to sexual harassment and abuse, and the demand to end patriarchal power structures in all workplaces-such as the so-called glass ceiling, structures that impede women from reaching top positions of power. At the same time, the usage of the pussy bow blouse as a symbol to capture these two feminist demands served to contest and reinterpret patriarchal notions of working women. The "secretary blouse" associated with submissive working women lacking agency is turned into a feminist symbol of working women challenging male power. The feminist interpretation of Sara Danius' resignation was questioned at the time of the Pussy Bow Blouse manifestation and had to be defended by those organising it. Four months after her resignation, Danius gave her own account of the crisis of the Swedish Academy and the Metoo-related events in a radio broadcast in which she emphasised the feminist significance (Danius, 2018). By pointing to the fact that women are more likely to report being victims of sexual crimes if there are women in leading positions in their work-places, she emphasised her own role in contributing to the charges pressed against the man related to the Swedish Academy by one of the victims in the time after the manifestation. Her contribution to the debate thus reinforced the association of the pussy-bow blouse with women's agency and resistance. This interpretation of the events was further strengthened in the fall of 2018 when the charges against the accused man led to a conviction for rape. The conviction was largely interpreted as a victory for the long-time struggle by feminist activists, lawyers, and researchers in Sweden to change legislation and attitudes towards sexual crimes and to a victory for the whole Metoo campaign. In the words of journalist Björn Wiman, the conviction was "written proof of how the Metoo movement changed the world" (Wiman, 2018). An appeal has later been lodged against this conviction. Sara Danius' recent appearance in a fashion show (fall 2018) dressed in a pussy bow blouse designed by her and decorated with the women's movement's symbol further links the pussy bow blouse to a feminist tradition of struggle and resistance in ways that will be hard to contest.

\section{Gender Equality and on Being a Victim}

Sweden's self-image as exceptional when it comes to gender equality has, it goes without saying, been severely damaged by the force and magnitude of the Swedish Metoo campaign that gathered 70,000 signatures in the fall of 2017 (Bendjelloul, 2018). In one blow the campaign delegitimises any self-assumed task of saving women in the rest of the world from patriarchal oppression. This implication of the Metoo campaign in Sweden gained the attention of international media, which gawked in surprise by the way the campaign sent shock-waves through Sweden, shaking the country's position as allegedly the world's most gender-equal country led by a feminist government (Silverberg, 2017). In this way, the Metoo campaign actualises the need to break with the worldview with roots in colonial feminism, as discussed earlier. There are further parallels with the Hijab Call-to-Action regarding the ways in which the notion of gender equality is addressed, as I will discuss in the following. In the feminist struggles and learning processes that the Metoo campaign initiated, the trope of the (secular), Swedish woman enjoying full gender equality seems to stand in the way of knowledge about real women's lives in equally powerful ways as in the case of the image of the subdued Religious Woman.

If the academic study of gender and religion needed to refute the prevailing images of religious women as lacking in self-determination and agency, the Metoo campaign is about the opposite: it shows that, contrary to prevailing ideas of an achieved gender equality, Swedish women in many cases have not had the capacity to exercise agency and say no to sexual oppression. The presence of a feminist discourse in Sweden seems to have added to the shame of being harassed or coerced; taken for granted that Swedes live in gender equality made it impossible to talk about certain realities. This is illustrated in the narratives concerning the man related to the Swedish Academy as the shame over not being able to say no was one of the reasons that kept the women silent for so many years. Only those women who could tell a story of how they hit back or stood up for themselves chose to appear with their names in the published narratives in the morning paper. As Swedish au- 
thor Johannes Anyuru (2018) remarked, the testimonies of the 18 women are painful to read because they manifest, to varying degrees, a vulnerability that existing (patriarchal) power relations made easy to exploit and, in some of the cases, a lack of agency (although Anyury does not use this word)-even of what in a theoretical language would be referred to as minimal agency, i.e., the capacity to be a cultural and political subject, and not a passive receiver of a culture defined by others. However, if for some, listening to and recognising the experiences expressed in testimonies like these is what the Metoo campaign is all about, other commentators have questioned such a reading. This latter view can be summarised as a questioning of adult women assuming an identity of victim, precisely as a person without self-determination.

I suggest that these debates reflect the same tensions that are shown in the veil controversies and that they point to one of the important knowledge projects that the Metoo campaign addresses. They have to do with the fact that feminism, at times, in different contexts, continues to be trapped in the binary model of the oppressed woman/the victim versus the gender-equal, or feminist, woman. There are similarities between the young religious women in the United Kingdom in Page's (2016) study referred to above, and the Swedish women coming forward about sexual harassment. For both categories of women, a discourse of gender equality and feminist consciousness seems to stand in the way of a true apprehension of their realities, generating shame instead of giving support. In this way, the activists of the Metoo campaign challenge a feminist academy to theorise further, or anew, experiences of victimisation, of agency, and resistance. An interview with Tarana Burke, by journalist Brockes (2017), offers food for thought. Brockes points out that even with the wave of testimonies brought forward by the Metoo campaign it is "still not exactly cool to out yourself as a victim of sexual violence." In the interview, Tarana Burke stresses that Metoo is about "the inherent strength in agency." I would like to align this knowledge project of the Metoo campaign with the theoretical discussions of women's religious agency. Theorising these fields together, which bring different perspectives to the table for discussion, would profit from, and contribute to, the further deconstruction of the binary oppressed/gender equal, a theoretical endeavour relevant to the entire field of intersectional feminism, and beyond.

\section{Solidarity and Intersectional Feminism}

The discussion of two recent solidarity campaigns in this article was framed in relation to a critique of what has been called Swedish exceptionalism, the notion that Sweden stands out as an exceptionally gender-equal country. Further, a point of departure was that the notion of a Swedish, perfect model of gender equality clashes both with the current situation in the country and with the wider goals of intersectional feminism. In my discussion, I asked how gender equality versus intersectionality was expressed and how they relate to the idea of Sweden as exceptional in this regard.

The collective learning processes triggered by these actions suggest that the idea of Sweden as exceptional needs to be abandoned-something which does not mean denying or abandoning the defence of what has been achieved in terms of gender equality up to the present. The Hijab Call-to-Action draws attention to the fact that Muslim women's possibilities to live gender equality in Sweden are constrained by racist, antimigration and sexist attitudes that are part of a transnational political landscape, and intensely debated in academic feminism. The scope and force of the Metoo campaign, as manifested in the Pussy Bow Blouse manifestation, shows that quite contrary to the ideal gender equality in workplace policies and legislation, the basic right not to be subjected to sexual violence is not respected in Sweden. Furthermore, taking a stand against sexism in the workplace signifies challenging deeply ingrained power structures that continue to shut out women from real power. Similarly to the Hijab Call-toAction, the transnational character of the Metoo campaign sets Sweden in relation to other countries, not as exceptional, but as one of many.

The Hijab Call-to-Action further sheds light on the location of the notion of gender equality in a secular progress narrative, which is problematically linked to what has been labelled colonial feminism. In this narrative, gender equality is caught in a binary form between the gender equal woman (the Western "us") and the oppressed woman (religious/colonised "others"). I tried to show that such a binary is still at work in academic thinking and public debate and actualised in the Metoo campaign. Martinsson et al. (2016) remark that gender equality often works as an empty concept, it is never defined but presupposed that everybody knows what it means. This, I would suggest, lies behind the ways in which the concept lends itself to tactical or polemic usages.

The activists of both campaigns urge feminist knowledge projects to go beyond the binary view of equality/oppression and recognise the complexities involved in each case. This entails for feminist knowledge projects a need to theorise powerlessness, self-determination, agency, and resistance further, with detailed, nuanced attention to each case in its social, cultural, and religious context.

The similarities in form between the two actions are related to their political content. Both the veil and the pussy bow blouse carry meanings that associate them with negative, patriarchal views of femininity, as submissive, passive, less worthy, less self-determinant, and not suitable to move in the public sphere on the same terms as men. At the same time, these patriarchal associations are precisely what enable the garments to turn into vehicles for protest: when joined with a feminist message, they were transformed into symbols of agency and resis- 
tance. The techniques of social media activism, including the established practice of sharing photos or selfies, made these campaigns particularly apt for mobilisation and for triggering debate.

At the core of both campaigns, it would seem, is the contestation of women's status as powerless or as victims in different contexts. However, this does not suggest that the actions represent a narrow view of gender equality-both actions speak to intersectional feminism in various ways. The Hijab Call-to-Action shows that gender, sexuality, race, religion, and global power relations all affect Muslim women's possibilities for equality-and for the conditions of the feminist struggle in Sweden generally. Further, it makes visible a norm of secularity, and challenges feminism to look at its own location in secular world-views critically.

The Metoo campaign brings with it the possibility of listening to as many voices as possible, not letting one category of women (or gender) be the sole testimonies to sexual abuse. This includes listening to the victims not only of heterosexual, male perpetrators, but to those who have been harassed or assaulted by nonheterosexual men or women who have held positions of power in their workplaces or associations (Holmberg, 2018). Furthermore, I would argue that the Metoo campaign's capacity to link the message of ending sexism and sexual abuse to the wider demand to change patriarchal and unjust power structures in all workplaces, as the protestors in the pussy bow blouse manifestation explain, creates a potential for fighting for change that goes far beyond the events related to the Swedish Academy. ${ }^{20}$ It opens a path for activism related to economic exploitation, work, class, ethnicity, and ability-forms of activism that would point directly at the actual state of gender equality in an intersectional perspective in Sweden today. The two campaigns discussed here address key areas of Swedish society and formulate concrete suggestions for political change, thus forcefully demonstrating that adopting policies of gender equality is not enough to respond to the reality of gender in the country. Further, both campaigns unequivocally show that feminist struggles do not relate only to "gender equality" - they intersect with a range of social and political struggles, and with wider knowledge projects. In fact, the similarity in form and technique of the two campaigns seem to suggest ways in which feminist identity politics open for such wider, intersectional struggles. The campaigns engage in feminist identity politics through a usage of the politics of clothing; garments that have been imbued with patriarchal notions of femininity-the Muslim headscarf and the pussy bow blouse-are reinterpreted and bestowed with new meanings that represent female bodies, their agency and relation to power in new ways. Both campaigns suggest, and the ways they enfold show, that the representation of female bodies in the public domain is heavily politicised, and not restricted to the clothing of Muslim women. ${ }^{21}$ By inviting people to take a stand in the political issues involved in the campaigns through the symbolic act of donning a scarf or a blouse, the campaigns invite identification with a harmed party, but at the same time suggest that the struggle does not regard support only for the category of woman that the garment allegedly represents; the symbolic act initiates a collective learning process that seeks to spell out the social and political issues at stake. So, whereas the Hijab Callto-Action represents a form of feminist identity politics protesting against the violence, discrimination, and misrepresentation of Muslim women in Swedish society, the campaign speaks to the political struggle against racism and xenophobia, in defence of migrants' rights and religious rights, violence towards women generally, Swedish feminism's relation to religion and so forth. The Pussy Bow Blouse campaign protests the handling of accusations of sexual abuse related to one institution but addresses the hierarchies of power in workplaces and institutions at large, and the right to freedom from sexual violence and abuse in all its width and complexity as it is raised in the Metoo campaign. The campaigns exhort activists to gather around the image of the veiled woman or the woman working in a male-dominated workplace to form a political coalition that includes people who do not belong to the categories of women allegedly represented in these images-a strategy to mobilise that proved to be effective in various ways.

To join the mere act of donning the garment was enough; men or feminist activists who did not own pussy bow blouses tied a bow around their neck to take a stand. Swedish women, many of whom Muslim, who do not wear hijabs in their daily life took any scarf they had to participate in the Hijab Call-to-Action. One could say that the techniques used in these campaigns reflect interplay between (feminist) identity politics and the workings of intersectional coalitions, as recently discussed by Hill Collins and Bilge (2016). These authors highlight that an understanding of identities as not fundamentally fixed and unchanging is important for seeing how intersectional coalition building can work. If identities are seen as strategical essentialist, in Gayatri Spivak's famous wording, the identities mobilised in political struggle can be understood as a "political practice whereby an individual group foregrounds one or more aspects of identity as significant in a given situation." (Hill Collins \& Bilge, 2016, p. 133). This enables the creation of a platform around which individuals or groups can gather. Hill Collins and Bilge further point out the advantages of seeing identities as already coalitional, a linking of identity politics and coalitional politics already present in Kimberley Crenshaw's work on intersectionality (Caras-

\footnotetext{
20 The activism related to Metoo and the Swedish Academy has further resulted in the creation of an alternative Academy that will distribute a literary award as an alternative to the withdrawn Nobel Prize in 2018.

21 The rise of the Sweden Democrats has brought about a new anti-feminist discourse in Swedish political life (Mulinari, 2016). In the electoral campaign of 2018, the Sweden Democrats suggested restrictions in the right to abortion, rupturing the political consensus in parliament on this issue.
} 
tathis, 2013; Crenshaw, 1991; Hill Collins \& Bilge, 2016). If identity politics "take place at the site where categories intersect" (Crenshaw, 1991, p. 1299; Hill Collins \& Bilge, 2016 , p. 134), the forming of groups based on identity is the result of a coalition between individuals (Hill Collins \& Bilge, 2016, p. 134). The feminist campaigns discussed here can be seen in line with this analysis: activists form a coalition around a platform of a temporary, unfixed identity represented by the woman dressed in a headscarf or blouse and invite others to form a wider, intersectional coalition with them. The inherent force in identity politics is used in the campaign appealing to solidarity through identification, but the contingent and coalitional nature of identity are highlighted in the act of dressing in a scarf or a blouse to wear a (political) identity for a day.

Finally, I would like to stress the fact that the two campaigns are strongly linked to international debate and transnational, feminist activism, not generated in an isolated Swedish struggle for gender equality. This brings hope; in this sense, the campaigns show a way out of Swedish exceptionalism and look for other ways of relating to and being in the world.

\section{Acknowledgments}

I thank the academic editors of this special issue and the two anonymous reviewers for their productive critique of earlier versions of this article. Furthermore, I am grateful to Helena Tolvhed and Klara Arnberg for sharing a forthcoming text on Metoo.

\section{Conflict of Interests}

The author declares no conflict of interests.

\section{References}

Abu-Lughod, L. (1986). Veiled sentiments: Honor and poetry in a Bedouin society. Berkeley, CA: University of California.

Abu-Lughod, L. (2002). Do Muslim women really need saving? Anthropological reflections on cultural relativism and its others. American Anthropologist, 104(3), 783-790.

Ahmed, L. (1992). Women and gender in Islam. New Haven, CT: Yale University Press.

Anyuru, J. (2018, May 30). "Vem vill ha ett pris från Svenska Akademin? Vill jag?" [Who wants a prize from the Swedish Academy? Do I?]. Dagens Nyheter. Retrieved from www. dn.se

Asad, T. (2003). Formations of the secular: Christianity, Islam, modernity. Stanford, CA: Stanford University Press.

Arnberg, K., \& Tolvhed, H. (2019). Nya plattformar för könspolitik. Kommentar till vittnesmål på sociala medier [New platforms for gender politics. Comments on testimonies in social media]. In K. Arnberg (Ed.), Könspolitiska nyckeltexter. Stockholm: Makadam för- lag. Manuscript submitted for publication.

Beattie, T. (2005). Religious identity and the ethics of representation: The study of religion and gender in the secular academy. In U. King \& T. Beattie (Eds), Gender, religion, and diversity. Cross-Cultural perspectives (pp 65-78). New York, NY: Continuum.

Bendjelloul, J. (2018, May 20). En mental berlinmur har rivits den kommer inte att byggas upp igen [A mental Berlin wall has been torn down and will not be rebuilt]. Dagens Nyheter. Retrieved from www.dn.se

Bracke, S. (2012). From 'saving women' to 'saving gays': Rescue narratives and their dis/continuities. European Journal of Women's Studies, 19(2), 237-252.

Bratt, A.-K. (2018, January 9). \#Metoo. Därför blev kampanjen så stor i Sverige [\#Metoo. Why the campaign grew so big in Sweden]. Feministiskt perspektiv. Retrieved from feministisktperspektiv.se

Brockes, E. (2017, January 15). Metoo founder Tarana Burke: You have to use your privilege serving other people. The Guardian. Retrieved from www.theguardian.com

Bynum, C., Walker, H. S., \& Richman, P. (Eds). (1986). Gender and religion: On the complexity of symbols. Boston, MA: Beacon Press.

Carastathis, A. (2013). Identity categories as potential coalitions. Signs, 38, 941-965.

Casanova, J. (1994). Public religions in the modern world. Chicago, IL: Chicago University Press.

Crenshaw, K. W. (1991). Mapping the margins: Intersectionality, identity politics, and violence against women of color. Stanford Law Review, 43, 1241-1299.

Cronin, S. (2014). Anti-veiling campaigns in the Muslim world gender, modernism and the politics of dress. New York, NY: Routledge.

Dahlberg-Grundberg, M. (2016). Digital media and the transnationalization of protests. Umeå: Umeå University, Department of sociology.

Danius, S. (2018, August 19). Sommar i P1 [Summer in P1]. Sveriges Radio. Retrieved from sverigesradio.se

Delshad, S. (2014, August 19). Sarah Delshad om mediebilden av slöjan ett år efter \#Hijabuppropet 2014 [Sara Delshad about the media image of the veil a year after the Hijab call-to-action]. Sveriges Radio. Retrieved from sverigesradio.se/sida/artikel. aspx?artikel=5941696

Dubisch, J. (1995). In a different place: Pilgrimage, gender and politics at Greek island shrine. Princeton, NJ: Princeton University Press.

Fanon, F. (1965). A dying colonialism. New York, NY: Grove Press.

Garcia, S. E. (2017, October 20). The women who created \#metoo long before hashtags. New York Times. Retrieved from www.nytimes.com

Gemzöe, L. (2000). Feminine matters. Women's religious practices in a Portuguese town. Stockholm: Stockholm University.

Gemzöe, L. (2009). Caring for others: Mary, death and 
the feminization of religion. In A.-K. Hermkens, C. Notermans, \& W. Jansen (Eds.), Moved by Mary: The power of pilgrimage in the modern world (pp. 149-163). Farnham: Ashgate.

Gemzöe, L., \& Keinänen, M.-L. (2016). Introduction: Contemporary encounters in gender and religion. In $\mathrm{L}$. Gemzöe, M.-L. Keinänen, \& A. Maddrell (Eds.), Contemporary encounters in gender and religion. European perspectives (pp. 1-28). Basingstoke: Palgrave MacMillan.

Gustavsson, M. (2017, November 18). 18 kvinnor: Kulturprofil har utsatt oss för övergrepp. [18 women: "Kulturprofil" has exposed us to abuse]. Dagens Nyheter. Retrieved from www.dn.se/kultur-noje/18-kvinnorkulturprofil-har-utsatt-oss-for-overgrepp

Hannan, R., \& Gabriel, T. (2011). Islam and the veil: Theoretical and regional contexts. London: Continuum.

Hermkens, A., Jansen, W., \& Notermans, C. (Eds.) (2009). Moved by Mary: The power of pilgrimage in the modern world. Aldershot: Ashgate.

Hill Collins, P., \& Bilge, S. (2016). Intersectionality. Cambrige, MA: Polity Press.

Holmberg, C. (2018). Paper presented at the mobile seminar of the Gender Academy, Stockholm University.

Holmqvist, J. (2018, April 13). Sara Danius alla traditioner är inte värda att bevara [Sara Danious: All traditons are not worth preserving ]. Aftonbladet. Retrieved from www.aftonbladet.se/nyheter

Jakobsen, J. R., \& Pellegrini, A. (Eds.). (2008). Secularisms. Durham and London: Duke University Press.

Jantzen, G. M. (1995). Power, gender and mysticism. Cambridge Studies in Gender and Religion. Cambridge: Cambridge University Press.

Khunke, A. B. (2018, April 13). Alice Bah Khunke dresses in pussy bow blouse. Retrieved from www. instagram.com/p/BhfylTnhVde

King, U. (Ed.). (2005). Religion and gender. Oxford and Cambridge: Blackwell.

Lindell, I. (2011). Transnational activism networks and gendered gatekeeping negotiating gender in an African Association of informal workers. Uppsala: Nordiska Afrikainstitutet.

Mahmood, S. (2005). Politics of piety: the Islamic revival and the feminist subject. Princeton, NJ: Princeton University Press.

Martinsson, L. (2016). Frictions and figurations: Genderequality norms meet activism. In L. Martinsson, G. Griffin, \& K. G. Nygren (Eds.), Challenging the myth of gender equality in Sweden (pp. 187-210). Cambridge, MA: Policy Press.

Martinsson, L., Griffin, G., \& Nygren, K. G. (Eds.). (2016). Challenging the myth of gender equality in Sweden. Cambridge, MA: Policy Press.

Mulinari, D. (2016). Gender equality under threat? Exploring the paradoxes of an ethno-nationalist political party. In L. Martinsson, G. Griffin, \& K. G. Nygren (Eds.), Challenging the myth of gender equality in Sweden (pp. 137-162). Cambridge, MA: Policy
Press.

Nilsson, E. (2018, April 20). Mona Sahlin och 2000 i knytblus manifestation [Mona Sahlin and 2000 in pussy bow blouse manifestation]. Dagens Opinion. Retrieved from dagensopinion.se

Ögren, A. (2018, November 11). Sara Mohammad: Jag blev tvingad att bära slöja och jag hatade den [I was forced to wear a veil and I hated it]. Metro. Retrieved from www.metro.se

Osman, B., Doubakil, F., Rouzbeh, F., Abdul Fattah, N., \& Libre, N. (2013, August 8). Imorgon beslöjar vi oss av solidaritet [Tomorrow we don the veil in solidarity]. Aftonbladet. Retrieved from www.aftonbladet.se

Page, S.-J. (2016). Navigating equality. Religious young women's perceptions of gender and sexuality equality. In L. Gemzöe L, M.-L. Keinänen, \& A. Maddrell, (Eds.), Contemporary encounters in gender and religion. European perspectives (pp. 131-150). Basingstoke: Palgrave MacMillan.

Pascalidou, A. (2017) Me too. Så går vi vidare. Röster, redskap och råd [Me too. How we move on. Voices, tools and advice]. Falun: Lava förlag.

Sands, K. (2008). Feminisms and secularisms. In J. R. Jakobsen \& A. Pellegrini (Eds.), Secularisms (pp. 308-329). Durham and London: Duke University Press.

Sauer, B. (2016). Gender and citizenship. Governing Muslim body covering in Europe. In L. Gemzöe, M.-L. Keinänen, \& a. Maddrell (Eds.), Contemporary encounters in gender and religion. European perspectives (pp. 105-130). Basingstoke: Palgrave MacMillan.

Scott, J. W. (2007). The politics of the veil. Princeton, NJ: Princeton University Press.

Sered, S. S. (1999). 'Woman' as symbol and women as agents: Gendered religious discourses and practices. In M. M. Ferree, J. Lorber, \& B. B. Hess (Eds.), Revisioning gender (pp. 193-221). Thousand Oaks and London: Sage Publications.

Silverberg, J. (2017, November 21). Därför uppmärksammas svenska metoo uppropen internationellt [Why the Swedish Metoo calls-to-action are given international attention]. Aftonbladet. Retrieved from www.aftonbladet.se

Tidningarnas telegrambyrå. (2018, April 14). Knytblusens feministiska historia [The feminist history of the pussy bow blouse]. Sveriges kvalitetssajt för nyheter. Retrieved from www.svd.se

Thomsson, U. (2000). Rätten till våra kroppar. Kvinnorörelsen och våldtäktsdebatten [The right to our bodies. The women's movement and the debate on rape]. Kvinnovetenskaplig tidskrift, 2000(4), 51-63.

van Luik, C. (Ed.). (2017). \#Metoo: 100 berättelser \& 10 frågor som behöver besvaras [\#Metoo : 100 stories $\& 10$ questions that need answer]. Stockholm: Max Ström.

Vuola, E. (2016). Feminist theology, religious studies and gender studies: Mutual challenges. In L. Gemzöe, 
M.-L. Keinänen, \& A. Maddrell (Eds.), Contemporary encounters in gender and religion. European perspectives (pp. 307-334). Basingstoke: Palgrave MacMillan.

Walton, H. (2016). The history of feminist theology in the academy: An autoethnographic research journey. In L. Gemzöe, M.-L. Keinänen, \& A. Maddrell (Eds.), Contemporary encounters in gender and religion. European perspectives (pp. 285-306). Basingstoke: Palgrave MacMillan.

Wiman, B. (2018, October 1). Just idag är Svenska Akademins bekymmer en bisak [Today the worries of the Swedish Academy are not the main issue]. $D a$ gens Nyheter. Retrieved from www.dn.se

Woodhead, L. (2014). Tactical and strategic religion. In N. M. Dessing, N. Jeldtoft, J. Nielsen, \& L. Woodhead (Eds.), Everyday lived Islam in Europe (pp. 9-22). Farnham and Burlington: Ashgate.

Woodhead, L. (2016). Afterword. In L. Gemzöe, M.-L. Keinänen, \& A. Maddrell (Eds.), Contemporary encounters in gender and religion. European perspectives (pp. 335-352). Basingstoke: Palgrave MacMillan.

\section{About the Author}

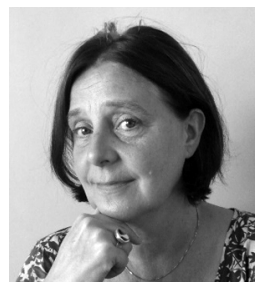

Lena Gemzöe is a Social Anthropologist and Professor of Gender Studies at Stockholm University with research interests in feminist theory, gender and religion, the anthropology of pilgrimage, reflexive ethnography, and culture studies. She has conducted fieldwork in Portugal, France, and Sweden. Recent books are the co-edited volume Contemporary Encounters in Gender and Religion: European Perspectives (Palgrave, 2016) and Feminism (updated edition in Swedish, 2014). 